\title{
Substrate preference by the porcelain crab Pachycheles monilifer (Crustacea, Anomura): the bryozoan Schizoporella errata or the polychaete Phragmatopoma caudata?
}

Ana Francisca Tamburus, Mariana Negri, Natália Rossi, Fernando L. Mantelatto and Luis Miguel Pardo*

(AFT, MN, NR, FLM) Laboratory of Bioecology and Crustacean Systematics (LBSC), Posgraduate Program in Comparative Biology, Department of Biology, Faculty of Philosophy, Science and Letters at Ribeirão Preto (FFCLRP), University of São Paulo (USP), Ribeirão Preto, São Paulo, Brazil. Emails: (AFT) anaftg@yahoo.com.br; (MN) mnegri@usp.br; (NR) nataliarossi.bio@gmail.com; (FLM) flmantel@usp.br

(LMP) Laboratorio Costero Calfuco, Instituto de Ciencias Marinas y Limnologicas, Universidad Austral de Chile, Casilla 567, Valdivia, Chile. Email: luispardo@uach.cl

${ }^{*}$ Corresponding author

\begin{abstract}
Differences on reproductive performance between two sampling points of the porcelain crab Pachycheles monilifer from Ubatuba (São Paulo, Brazil), one from Itaguá Beach (living on Schizoporella errata) and the other from Grande Beach (living on Phragmatopoma caudata) has been previously observed. Therefore could be expected a specific behavior in substrate preference to optimize the best biogenic habitat. Considering this premise, our goal was to test the substrate preference of this species when both substrates were simultaneously available. In total, 185 individuals were collected in these same localities and they were submitted to substrate selection experiments. The trials were conducted on containers with quiet seawater at $28 \pm 1^{\circ} \mathrm{C}$ and under dark photoperiod. Specimens were exposed to substrates by $30 \mathrm{~min}$. Trials started with the release of one animal per treatment in the middle of the opposite side to the substrate inside the containers. After the established time, the substrate preference of each porcelain crab was verified. As result, no preference pattern was found and the choices in the experiment were not significantly different from the expected. This lack of preferences may be an indication that porcelain crabs are generalists in habitat use regardless of sex of individuals and potential benefit in fitness. Therefore, the differences on the reproductive aspects of the $P$. monilifer probably are associated with environment factors not simulated in this study and may indicate the occurrence of plasticity in habitat selection behavior.
\end{abstract}

Key words: Behavior, habitat, plasticity, Porcellanidae, trials

\section{INTRODUCTION}

Decapod crustaceans that live in microhabitats with well-defined boundaries in the structure of sessile marine macro-invertebrates represent an appropriate model for investigations on preference habitat (Baeza and Stotz, 2003).
Usually, these microhabitats are relatively easy to manipulate, making it possible to test habitat preferences by means of laboratorial experiments (Baeza and Stotz, 2003). When choosing among different habitats, some decapods, including the porcelain crabs, can 
respond to various chemical and physical habitat characteristics probably involving the combination of multiple sensory modalities to recognize and discriminate them (Ache and Davenport, 1972; Brooks and Rittschof, 1995; Guo et al., 1996; Baeza and Stotz, 2003; Montfrans et al., 2003).

Many factors may contribute to the decapods habitat choice, such as the occurrence of adult conspecifics [e.g. Petrolisthes cinctipes (Randall, 1840) and $P$. eriomerus Stimpson, 1871 by Jensen, 1989; Uca pugnax (Smith, 1870) by O'Connor and Van, 2006], light features of crevices, habitat structural characteristics, habitat-related chemical cues and avoidance of potential predators (see Montfrans et al., 2003 for last factors). The availability of food and the secure place for reproduction and development also influencethis preference (Mantelatto and Souza-Carrey, 1998).

Understanding the preference for one habitat over another is one of the most important factors to explain the distribution and abundance of decapods in the field. In this way, the knowledge about variations in the abundance and distribution of these crustaceans are useful to recognize the process structuring in marine benthic populations and communities (Hedvall et al., 1998; Baeza and Stotz, 2003).

Within the infraorder Anomura MacLeay, 1838, some members of the family Porcellanidae Haworth, 1825 show a strait relationship with some biogenic substrates. They can be found inhabiting sessile colonies of sea urchin, startfishes, gastropods, bryozoans and polychaetes (Gore et al., 1978; Baeza and Stotz, 2001; 2003). Some symbiotic porcellanid species live in aggregations on their hosts with members of both sexes, others are found in isolated heterosexual pairs per host or living solitarily (for references see Baeza et al., 2002).

In particular, Pachycheles monilifer (Dana, 1852), a common porcelain crab distributed on the Western Atlantic Ocean, from Florida (USA) to southern Brazil, and on Eastern Pacific (Ecuador and Peru) (Veloso and
Melo, 1993; Rodríguez et al., 2005), has been recorded living under rocks (Melo, 1999), in biological substrates such as the bryozoans and polychaetes (Gore et al., 1978; Pinheiro et al., 1997; Mantelatto and Souza-Carrey, 1998; Hattori and Pinheiro, 2001) and associated with living mussels and the mussel farming ropes (Macedo et al., 2012). This small crab, which is coexistent with other porcellanid species, can be easily distinguished from the congeners by the disposition and pubescence of some characteristic tubercles in the chelipeds (Haig, 1960; Gore and Abele, 1976).

In Ubatuba region, northern coast of São Paulo (Brazil), P. monilifer either lives associated with sandy reefs formed by aggregations of individual compact sand tubes of the native polychaetes Phragmatopoma caudata (Kröyer, 1856), or in large galleries of the branching forms of the non-native bryozoan Schizoporella errata (Waters, 1878) (Gore et al., 1978; Bradstock and Gordon, 1983; Maluquer, 1985; Mantelatto and SouzaCarrey, 1998; Ferdeghini and Cocito, 1999; Hattori and Pinheiro, 2001). The species was also recorded for areas of rocky shore in small pools formed during low tide (Silva, 2011).

The polychaetes of the genus Phragmatopoma plays an important role as bioengineer of microhabitats for many invertebrates with its ability of forming extensive "reefs" or bioherms in shallow/ intertidal marine waters using sand particles and a mucoproteinaceous cement. Commonly, large sandbanks are formed in surf wave zones, especially in areas exposed to the open sea (Gore et al., 1978). These sandbanks also offer shelter and food resource to different organisms (Wilson, 1979).

Schizoporella errata was first described from Naples, Italy and appears to be native to the Mediterranean. This invasive species is now widespread throughout the world's warmer waters (Hayward and Ryland, 1999; ISSG, 2011). In general, the bryozoans of the genus Schizoporella can be found in areas with hydrodynamic activity. However, they are common in shallow and calm waters with high concentrations of organic matter 
(Gusso-Chimenz and Rivosecchi-Taramelli, 1972 in Cocito et al., 2000; Leone and Mantelatto, 2015). The constructional pattern of the Schizoporella colonies results from the interaction with other organisms and hydrodynamic conditions (Cocito et al., 2000). Their complex structure offers shelter to a very diverse associated fauna of invertebrates (Mantelatto and Souza-Carrey, 1998; Morgado and Tanaka, 2001).

Although both species, $P$. caudata and $S$. errata, could occur in both infralittoral and shallow subtidal region in rocky shores and form colonies, they are not found together or in the same environment at Ubatuba region. They are very different in terms of size, design and external and internal geometrical structure (Leone and Mantelatto, 2015). Phragmatopoma caudata forms galleries with internal spaces more restricted than the $S$. errata.

A previous study developed by Leone and Mantelatto (2015) compared key reproductive aspects between populations of $P$. monilifer inhabiting these two types of substrate from Ubatuba, São Paulo. These authors found that the specimen sizes, including the ovigerous females, from the bryozoan substrate are larger than those from the polychaete, as well as their fecundity and reproductive output. According to them, some factors, as the restricted internal space in the polychaete substrate and the high local hydrodynamics, may represent limitations to the animal growth (Leone and Mantelatto, 2015).

Considering this baseline and the highest reproductive performance of $P$. monilifer when in $S$. errata, the present study tests in laboratory the optimal substrate preference hypothesis, in which porcelain crabs should select the substrate that improves the reproductive axes of their fitness when $S$. errata and $P$. caudata fragments were simultaneously available.

\section{Material And Methods}

Collection of Specimens and Study Sites

In total, 185 specimens of the porcelain crab P. monilifer (Tab. 1) were collected, being 127 individuals $(56$ males, 55 females, 16 juveniles) found in the sandbanks of the polychaete $P$. caudata from Grande Beach $\left(23^{\circ} 28^{\prime} 02^{\prime \prime} \mathrm{S}-45^{\circ} 35^{\prime} 35^{\prime \prime} \mathrm{W}\right)$. This collection site is an exposed beach, which suffers the wave impacts on the rocky shore and makes it turbulent (Leone and Mantelatto, 2014). Colonies of the polychaete were removed manually by two people and packed in plastic bags for further screening of the animals. The salinity of local water was 30.8 and temperature $22^{\circ} \mathrm{C}$. These sandbanks were chosen and kept alive as one of the substrate employed in the experiments of this study.

In Itaguá Beach $\left(23^{\circ} 27^{\prime} 05^{\prime \prime} \mathrm{S}\right.$ $\left.45^{\circ} 02^{\prime} 48^{\prime \prime W}\right), 58$ individuals of $P$. monilifer (24 males, 20 females, 14 juveniles) (Tab. 1) were obtained from the colonies of the bryozoan $S$. errata incrusted in a pier. This site is characterized as a sheltered local inside a bay with moderate wave motion (Leone and Mantelatto, 2015). The bryozoan colonies were sampled and used as substrate in the laboratory choice experiment (see below). To remove the bryozoan colonies from the pier, snorkeling was performed by two people, colonies were packed in plastic bags and the animals were posteriorly separated. The local salinity was 31.6 and temperature $20^{\circ} \mathrm{C}$. Both collection sites are in Ubatuba, northern coast of São Paulo State in Brazil (Fig. 1).

The identification was confirmed based on the diagnostic morphological traits (Melo, 1999). Porcelain crabs were checked in terms of sex, females with gonopore on the third pereiopods and pleopods on abdomen, and

Table 1. Carapace length of the porcelain crab Pachycheles monilifer collected in Ubatuba, northern coast of São Paulo State in Brazil (Min: minimum; Max: maximum; SD: standard deviation).

\begin{tabular}{|c|c|c|c|c|c|c|c|c|c|c|}
\hline \multirow[b]{2}{*}{ Carapace Length (mm) } & \multirow[b]{2}{*}{$\mathbf{N}$} & \multicolumn{4}{|c|}{ Itaguá Beach - S. errata } & \multirow[b]{2}{*}{$\mathbf{N}$} & \multicolumn{4}{|c|}{ Grande Beach - P. caudata } \\
\hline & & Min & $\operatorname{Max}$ & Mean & SD & & Min & $\operatorname{Max}$ & Mean & SD \\
\hline Male & 24 & 4.1 & 8.8 & 5.6 & 1.2 & 56 & 3.8 & 10.0 & 7.0 & 1.5 \\
\hline Female & 20 & 3.8 & 9.3 & 5.8 & 1.7 & 55 & 3.2 & 9.7 & 6.8 & 1.4 \\
\hline Juvenil & 14 & 3.2 & 4.9 & 3.9 & 0.6 & 16 & 2.7 & 4.0 & 3.3 & 0.4 \\
\hline Total & 58 & 3.2 & 9.3 & 5.4 & 1.6 & 127 & 2.7 & 10.0 & 6.6 & 1.8 \\
\hline
\end{tabular}




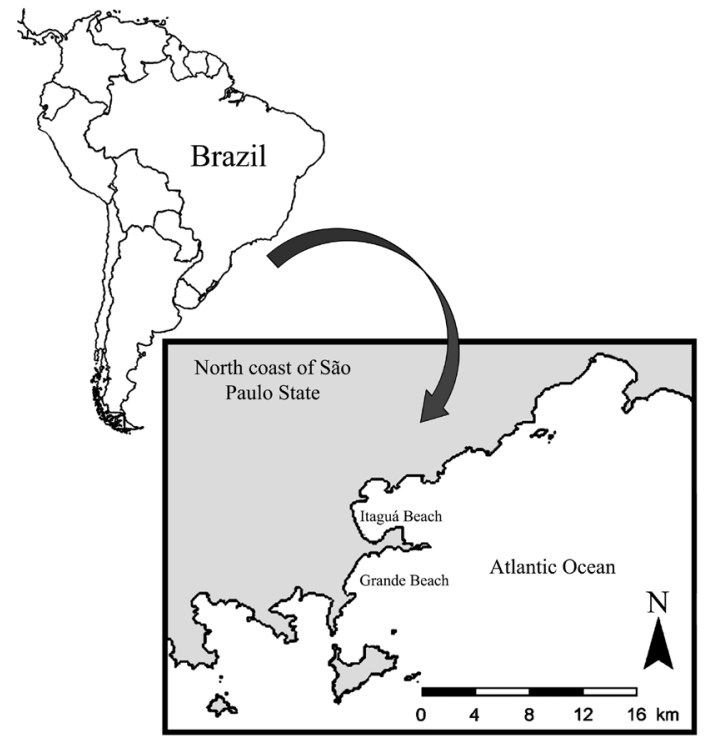

Figure 1. Map of the north coast of São Paulo (Brazil) showing Grande and Itaguá Beaches in Ubatuba city (redrawn and modified from Barros-Alves, 2013).

males without pleopods (Melo, 1999; Hattori and Pinheiro, 2001; Silva, 2011). The individuals were identified as adult or juvenile based on the size of the smallest ovigerous obtained (Ahmed and Mustaquim, 1974; Oliveira and Masunari, 1995). We decided to perform the experiments only with adults, without distinguishing ovigerous from other females because the number of collected juveniles and females bearing eggs were very low, making impossible a minimum number of replications for reliable analyses. The carapace length $(\mathrm{CL}=$ from the posterior to the anterior margin) was obtained with a vernier caliper (accuracy 0.01 $\mathrm{mm})$. After substrates choice experiment they were preserved in ethanol $(80 \%)$ and voucher specimens were deposited in Crustacean Collection of the Biology Department (CCDB 5179) of the Faculty of Philosophy, Sciences and Letters at Ribeirão Preto (FFCLRP) at the University of São Paulo (USP) (Permanent license for Crustacean Collection No. 071/2012/SECEX/CGEN).

\section{Substrate selection}

In total, 58 individuals from each collection site were used to test the substrate selection. A full factorial designed was performed with origin (substrate where the individual crab was collected) and substrate (Schizoporella or Phragmatopoma) as factors. Each trial was run for 30 minutes (observations: 10 in $10 \mathrm{~min}$ ) where one individual was exposed to both substrates in an experimental arena. Replications to each treatment were performed, 10 for males and 12 for females.

Experimental unit was each container $(15.5 \mathrm{~cm}$ height $\mathrm{cm} ; 24 \mathrm{x} 24 \mathrm{~cm}$ area of bottom). This had a fragment of polychaete and other of bryozoan substrate of similar volume placed in each corner of the same side (Containers 1 and 2, Fig. 2). Containers were filled with seawater $(3.5 \mathrm{l})$ and gentle aereted. One container only with bryozoan substrates and other only with polychaete substrate were used as controls (Fig. 2). To eliminate the effects of other animals associated to colonies, the fragments of substrates, they were sank in freshwater $(30 \mathrm{~min})$ followed by seawater (40 $\mathrm{min})$ to return to the initial conditions. One individual porcelain crab per treatment was released in the middle of the opposite side to the substrate of the experimental arena and then the chronometer was triggered. In this start point, the animal was equidistant from each substrate $(26.8 \mathrm{~cm})$. During the experiments, a dark photoperiod was simulated by the use of a black canvas over the containers.

Each animal was used only once in the experiment in order to avoid any behavior acquired. The results for the control trials were designated according to the sides of the chosen substrate piece, left or right. Analysis of the data was made using STATISTICA ${ }^{\oplus}$, version 8.0 (StatSoft, 2007), adopting the significance level $\alpha<0.05$. The Chi-square $\left(\chi^{2}\right)$ test was used to check the sex-ratio. This test was also employed to detect if the animals showed a biases in the substrate choice in respect to random expected choice and on control trials to test a preference for one of the two sides, what could indicate the existence of other variables influencing their direction. We employed the Chi-square test to verify the substrate preference; we randomly grouped the specimens used within replications in three groups, two with ten and one with nine replications. 


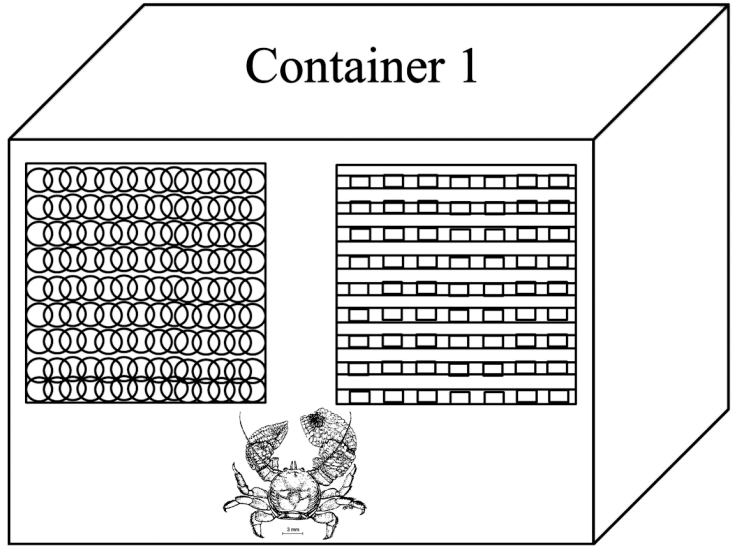

crab from S. errata

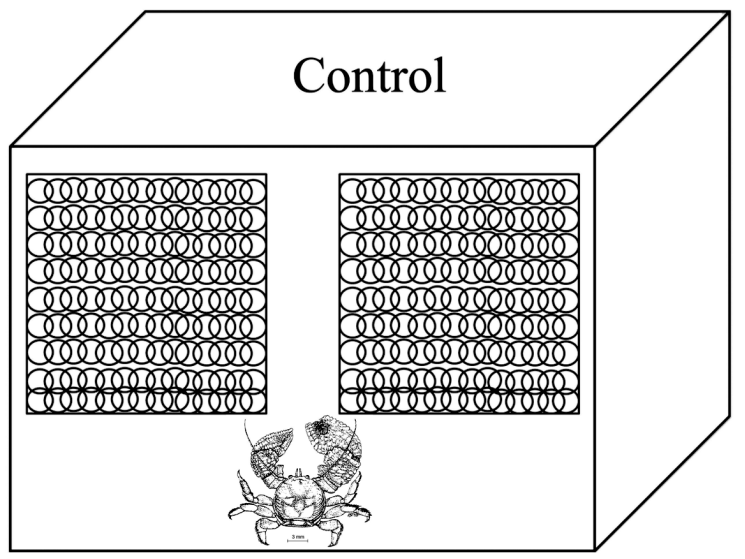

crab from $S$. errata

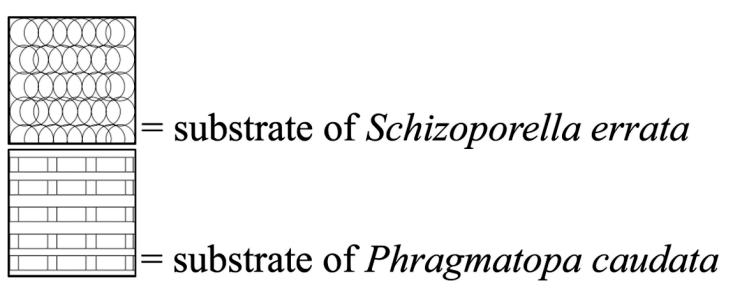

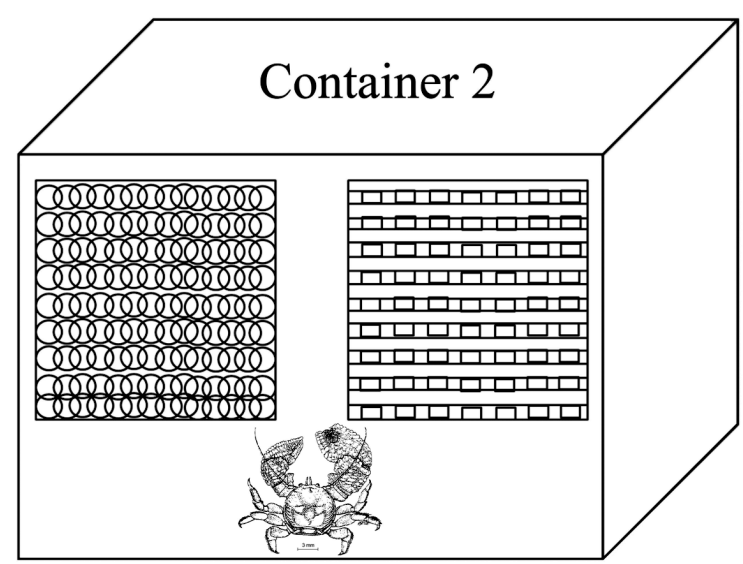

crab from $P$. caudata

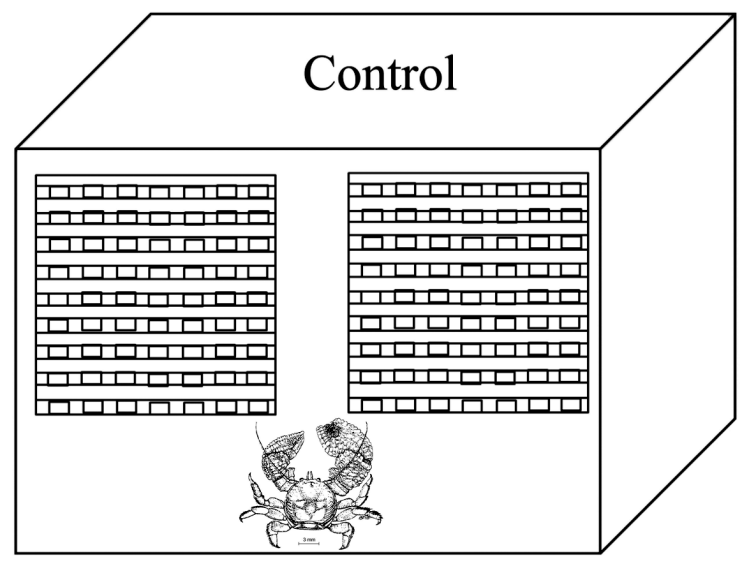

crab from $P$. caudata

Figure 2. Diagram representing the layout of the experiment designed to test substrate selection by the porcelain crab Pachycheles monilifer (crab redrawn and modified from Micheletti-Flores and Negreiros-Fransozo, 1999).

\section{RESUlTS}

In the experimental arena with only one type of substrate, $S$. errata or $P$. caudata (controls), the choice of left or right exhibited by individuals of $P$. monilifer was not significantly different from the expected $(50 \%$ for each side; $p$ $>0.05)$. In general individuals have not a preference in the choice by the same substrate that they were collected (Fig. 3 and Tab. 2; $p>$ $0.05)$. Considering the sex separately, there was a tendency for selection of the substrate. Males of porcelain crab kept the original substrates and only females from $P$. caudata changed the substrate (Fig. 4). However, these choices also were not statistically different from the expected $(p>0.05)$. Therefore, P. monilifer did not show preferences for the substrates selected. Analyzing sex ratio on both sort of substrate separately and the total number, no significant deviation of 1:1 was observed (Tab. 3). 


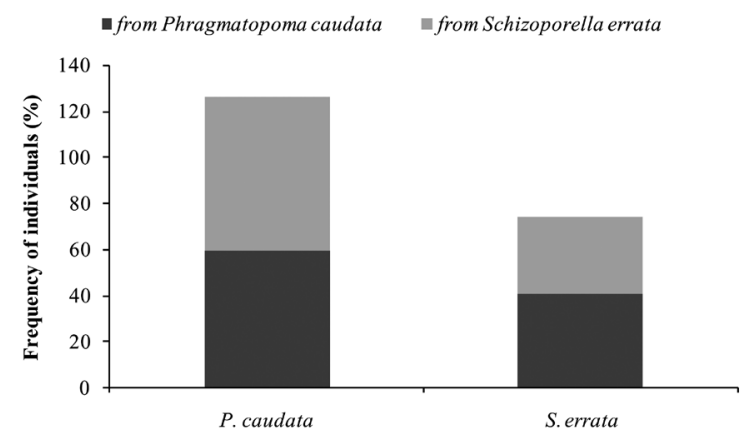

Figure 3. Pachycheles monilifer. Frequency of relative preference according to the substrate that they were sampled.

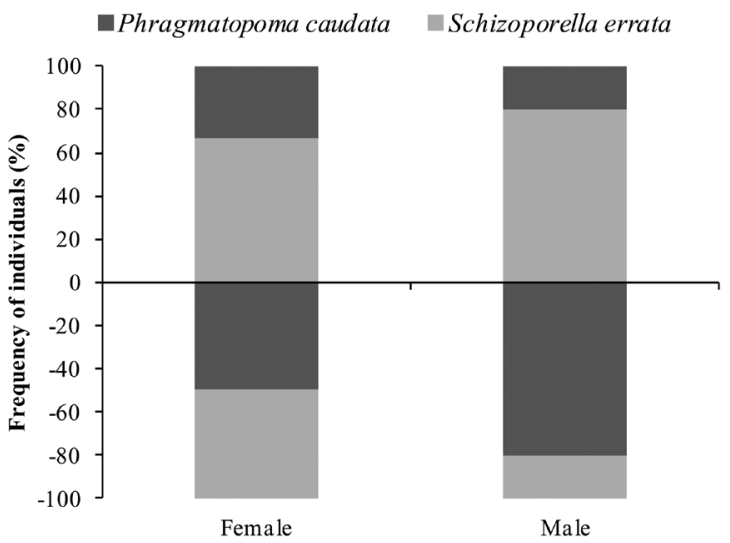

Figure 4. Pachycheles monilifer. Frequency by sex according to the relative preference to the substrate that they were sampled. Above (positive axis) individuals came from Schizoporella errata and below (negative axis) they came from Phragmatopoma caudata.

Table 2. Chi-square test for substrate preference exhibited by individuals of the species Pachycheles monilifer. It was quantified during the experiment and randomly grouped specimens used in replications within three groups (P: P. caudata; S: S. errata; p: significance level $\chi^{2}$ : chi-square).

\begin{tabular}{|c|c|c|c|c|c|c|}
\hline & \multicolumn{3}{|c|}{ S. errata } & \multicolumn{3}{|c|}{ P. caudata } \\
\hline & $\mathbf{P}$ & $S$ & Expected & $\mathbf{P}$ & $S$ & Expected \\
\hline Group 1 & 7 & 2 & 4.5 & 3 & 6 & 4.5 \\
\hline Group 2 & 8 & 2 & 5 & 6 & 4 & 5 \\
\hline Group 3 & 6 & 4 & 5 & 3 & 7 & 5 \\
\hline$\chi^{2}=3.3$ & & & $=0.18$ & $\chi^{2}=1.5$ & & $=0.47$ \\
\hline
\end{tabular}

Table 3. Sex ratio (Male: Female) on both sort of substrate separately and considering the total number $(\mathrm{N}$ : number of individuals; $\chi^{2}$ : chi-square).

\begin{tabular}{cccc}
\hline $\mathbf{N}$ & P. caudata & S. errata & Total \\
\hline Male & 56 & 24 & 80 \\
Female & 55 & 20 & 75 \\
Sex-ratio & 1.02 & 1.20 & 1.07 \\
$\boldsymbol{X}^{\mathbf{2}}$ & 0.01 & 0.36 & 0.16 \\
\hline \hline
\end{tabular}

\section{DisCUSSION}

Our findings proposed that adults of $P$. monilifer do not have a preferential selection between the substrates: the polychaete $P$. caudata and the bryozoan $S$. errata. The animals were put in an artificial environment with these two different substrates simultaneously available. Additionally, a random choice by the porcelain crabs in the control trials indicated the absence of any external factor influencing the direction choice.

In each collection site, there is only one kind of accessible substrate for these crabs. As already mentioned, in Grande Beach they are found on the sandbanks of the polychaetes and in Itaguá Pier there are only bryozoan colonies. Each one of these localities is in the opposite side of a peninsula, with about 1.8 miles of distance between them. The collection point on Grande Beach is located in an exposed region in rocky intertidal and on Itaguá Pier is positioned in a protected region with about 3 meters depth. Pachycheles monilifer is abundant in both localities and use these two substrates as shelter or/and food resource (Pinheiro et al., 1997; Micheletti-Flores and NegreirosFransozo, 1999; Alves et al., 2011; 2013; Leone and Mantelatto, 2015).

Although P. monilifer reveals to achieve a better reproductive performance when associated with $S$. errata instead of $P$. caudata (Leone and Mantelatto, 2015), this benefit does not influence its choice. Differences on reproductive aspects can be associated to particularities in the environment conditions in nature of each collection site. However, in artificial conditions, it is not possible to reproduce all the natural features. In this case the individual choice is random.

If the environmental conditions were strictly simulated, a preference pattern could have been found. Likewise, species of porcelain crabs demonstrated loyalty to the anemones in/of subtidal waters, but tend to change of host of intertidal areas (Thiel et al., 2003). This behavior indicated that intertidal areas are less favorable to its inhabitants, since these habitats are subject to daily periods of low tide. According to Leone and Mantelatto 
(2015), in the bryozoan substrate the stress seems to be smaller than in the polychaetes substrate, probably because of differences on the local hydrodynamics, the competition against sympatric species of porcellanids and a restriction of the internal space of the polychaetes substrate.

These animals use their third maxillipeds as food nets, to sweep suspended material and plankton from the water column, which are important to survival (Gore et al., 1978; Pinheiro et al., 1997). Nevertheless, the specimens of both sexes look firstly for a local to protection, without differentiating the kind of substrate by source of feed, consequently, showing no preference. On the other hand, others axes of fitness (survival, growth) can balance the benefit of one or another habitat. Pachycheles monilifer can be considerate a host generalist. The existence of this diversity within the same population can be understood as an element of biocomplexity (Hilborn et al., 2003). However, in a population scale, the results could be different and it would be expected a preference for the bryozoans, once P. monilifer reproduction performance in such substrate is improved (Leone and Mantelatto, 2015). Nonetheless, the differences on the reproductive aspects probably are associated with environment factors not simulated in this study and may indicate the occurrence of plasticity in behavior. This biocomplexity within a population would be important for maintaining its resilience to future environmental change, as detected for fish stocks (Hilborn et al., 2003).

In addition, $S$. errata is apparently less abundant and more discontinuous than P. caudata in the sampling local and it is known that different environmental features, complexity and abundance of the host or substrates interfere in the social behavior of the inhabitant (Baeza and Thiel, 2000). Apart from these characteristics, some other ecological and behavioral factors might influence the choice, such as the animals' density (Micheletti-Flores and Negreiros-Fransozo, 1999).

Moreover, many invertebrates elect a particular habitat during their initial stages in dispersion (Brown and Lomolino, 2006) such as the larvae of the southern king crab Lithodes santolla (Molina, 1782) that prefer substrates with a high number of interstitial spaces to shelter (Cocito et al., 2000). The absence of studies about larvae recruitment or in the first juvenile phases of the $P$. monilifer maintained a gap on this information. Therefore, as far as we know, this is the only experimental study until now that contribute to the understanding the habitat choice of this species and further studies should be stimulated in order to better understand the selection substrate in the porcelain group.

ACKNOWLEDGEMENTS - This report is a result of activities during the postgraduate course (Experimental Marine Biology - FFCLRP/USP). We gratefully acknowledge the Department of Biology, Postgraduate Program in Comparative Biology of the FFCLRP/ USP and Pró-Reitoria de Pós-Graduaçáo da USP for partial financial support and Fundação de Amparo à Pesquisa do Estado de São Paulo - FAPESP (Biota 2010/50188-8) for additional support and cover costs of LMP during Brazilian visit. FLM received research scholarship from CNPq (302748/2010-5), MN from FAPESP (2012/06300-3) and NR from CAPES. All experiments conducted in this study complied with current applicable state and federal laws of Brazil.

\section{REFERENCES}

Ache, B.W. and Davenport, D. 1972. The sensory basis of host recognition by symbiotic shrimps, genus Betaeus. Biological Bulletin, 143(1): 94-111.

Ahmed, M. and Mustaquim, J. 1974. Population structure of four species of porcellanid crabs (Decapoda: Anomura) occurring on the coast of Karachi. Marine Biology, 26(2): 173-182.

Alves, D.F.R.; Barros-Alves, S.P.; Lima, D.J.M. and Cobo, V.J. 2011. Composition and abundance of porcellanid crabs (Crustacea: Decapoda: Anomura) from rocky bottoms off Vitória Island, southeast coast of Brazil. Zoologia, 28(2): 214-218.

Alves, D.F.R.; Barros-Alves, S.P.; Lima, D.J.M.; Cobo, V.J. and Negreiros-Fransozo, M.L. 2013. Brachyuran and anomuran crabs associated with Schizoporella unicornis (Ectoprocta, Cheilostomata) from southeastern Brazil. Annals of the Brazilian Academy of Sciences, 85(1): 245-256.

Baeza, J.A. and Thiel, M. 2000. Host use pattern and life history of Liopetrolisthes mitra (Dana, 1852), an associate of the black sea urchin Tetrapygus niger (Molina). Journal of Marine Biological Association of United Kingdom, 80(4): 639-645.

Baeza, J.A. and Stotz, W.B. 2001. Host-use pattern and host-selection during ontogeny of the commensal crab Allopetrolisthes spinifrons ( $\mathrm{H}$. Milne Edwards, 1837) (Decapoda: Anomura: Porcellanidae). Journal of Natural History, 35(3): 341-355. 
Baeza, J.A. and Stotz, W.B. 2003. Host-use and selection of differently colored sea anemones by the symbiotic crab Allopetrolisthes spinifrons. Journal of Experimental Marine Biology and Ecology, 284(1): 25-39.

Baeza, J.A.; Stotz, W. and Thiel, M. 2002. Agonistic behavior and development of territoriality during ontogeny of the sea anemone dwelling crab Allopetrolisthes spinifrons (A. Milne-Edwards, 1837) (Decapoda: Anomura: Porcellanidae). Marine and Freshwater Behaviour and Physiology, 35(4): 189202.

Barros-Alves, S.P. 2013. Ocupação de substratos artificiais por caranguejos braquiúros (Crustacea, Decapoda) no sublitoral rochoso do Ilhote das Couves, litoral norte paulista. PhD Thesis. Universidade Estadual Paulista "Júlio de Mesquita Filho" - Botucatu. 113pp.

Bradstock, M. and Gordon, D.P. 1983. Coral-like bryozoan growths in Tasman Bay, and their protection to conserve commercial fish stocks. New Zealand Journal of Marine and Freshwater Research, 17(2):159-163.

Brooks, W.R. and Rittschof, D. 1995. Chemical detection and host selection by the symbiotic crab Porcellana sayana. Invertebrate Biology, 114(2): 180185.

Brown, J.H. and Lomolino, M.V. 2006. Biogeografia. FUNPEC, 691pp.

Cocito, S.; Ferdeghini, F.; Morri, C. and Bianchi, N.C. 2000. Patterns of bioconstruction in the cheilostome bryozoan Schizoporella errata: the influence of hydrodynamics and associated biota. Marine Ecology Progress Series, 192: 153-161.

Ferdeghini, F. and Cocito, S. 1999. Biologically generated diversity in two bryozoan buildups. Biologia Marina Mediterranea, 6(1):191-197.

Gore, R.H. and Abele, L.G. 1976. Shallow water porcelain crabs from the Pacific Coast of Panama and adjacent Caribbean waters (Crustacea: Anomura: Porcellanidae). Smithsonian Contributions to Zoology, 237: 1-30.

Gore, R.H.; Scotto, L.E. and Becker, L.J. 1978. Community composition, stability and trophic partitioning in decapod crustaceans inhabiting some subtropical sabellariid worm reefs. Bulletin Marine Science, 28(2): 221-248.

Guo, C.C.; Hwang, J.S. and Fautin, D.G. 1996. Host selection by shrimps symbiotic with sea anemones: a field survey and experimental laboratory analysis. Journal of Experimental Marine Biology and Ecology, 202: 165-176.

Gusso-Chimenz, C. and Rivosecchi-Taramelli, E. 1972. Contributo alla conoscenza dei briozoi del porto di Civitavecchia. Atti V Congresso Nazionale della Società Italiana di Biologia Marina SIBM Genova, 66-101.

Haig, J. 1960. The Porcellanidae (Crustacea: Anomura) of the Eastern Pacific. Allan Hancock Pacific Expedition, 24: 1-440.

Hattori, G.Y. and Pinheiro, M.A.A. 2001. Fecundity and embryology of Pachycheles monilifer (Dana, 1852) (Anomura, Porcellanidae) at Praia Grande, Ubatuba, SP, Brazil. Nauplius, 9(2): 97-109.

Hayward, P.J. and Ryland, J.S. 1999. Cheilostomatous Bryozoa: 2 Hippothooidea - Celleporoidea: notes for the identification of British species. 2nd Ed. Synopses of the British fauna, new series, 14, 416p.
Hedvall, O.; Moksnes, P.O. and Pihl, L. 1998. Active habitat selection by megalopae and juvenile shore crabs Carcinus maenas: a laboratory study in an annular flume. Hydrobiologia, 375/376: 89-100.

Hilborn, R.; Quinn, T.P.; Schindler, D.E. and Rogers, D.E. 2003. Biocomplexity and fisheries sustainability. Proceedings of the National Academy of Sciences of the United States of America, 100(11): 6564-6568.

ISSG. 2011. Global Invasive Species Database (GISD). Invasive Species Specialist Group of the IUCN Species Survival Commission. http:// http://www. issg.org/database/species/ecology.asp? $\mathrm{si}=1084 \& \mathrm{fr}=1$ \&sts=sss \&lang=EN

Jensen, G.C. 1989. Gregarious settlement by megalopae of the porcelain crabs Petrolisthes cinctipes (Randall) and P. eriomerus Stimpson. Journal of Experimental Marine Biology and Ecology, 131: 223-231.

Leone, I.C. and Mantelatto, F.L. 2015. Maternal investment in egg production: substrate and population-specific effects on offspring performance of the symbiotic crab Pachycheles monilifer (Anomura: Porcellanidae). Journal of Experimental Marine Biology and Ecology, 464: 18-25.

Macedo, P.P.B.; Masunari, S. and Corbetta, R. 2012. Crustáceos decápodos associados às cordas de cultivo do mexilhão Perna perna (Linnaeus, 1758) (Mollusca, Bivalvia, Mytilidae) na Enseada da Armação do Itapocoroy, Penha - SC. Biota Neotropica, 12(2). http://www.biotaneotropica.org. $\mathrm{br} / \mathrm{v} 12 \mathrm{n} 2 / \mathrm{pt} / \mathrm{abstract?}$ inventory+bn01812022012

Maluquer, P. 1985. Algunas consideraciones sobre la fauna asociada a las colonias de Schizoporella errata (Waters, 1878) del puerto de Mahon (Menorca, Baleares). Publicaciones del Departamento de Zoología. Universidad de Barcelona, 11:23-28.

Mantelatto, F.L. and Souza-Carrey, M.M. 1998. Brachyura (Crustacea, Decapoda) associated to Schizoporella unicornis (Bryozoa, Gymnolaemata) in Ubatuba Bay (SP), Brazil. Brazilian Archives of Biology and Technology, 41(2): 212-217.

Melo, G.A.S. 1999. Família Porcellanidae. In: Melo, G.A.S. Manual de identificação dos crustacea decapoda do litoral brasileiro: Anomura, Thalassinidea, Palinuridae, Astacidea. Editora Plêiade/FAPESP, pp. 214-269.

Micheletti-Flores, C.V. and Negreiros-Fransozo, M.L. 1999. Porcellanid crabs (Crustacea, Decapoda) inhabiting sand reefs built by Phragmatopoma lapidosa (Polychaeta, Sabellariidae) at Paranapuã Beach, São Vicente, SP, Brazil. Revista Brasileira de Biologia, 59(1): 63-73.

Montfrans, J.; Ryer, C.H. and Orth, R.J. 2003. Substrate selection by blue crab Callinectes sapidus megalopae and first juvenile instar. Marine Ecology Progress Series, 260: 209-217.

Morgado, E.H. and Tanaka, M.O. 2001. The macrofauna associated with the bryozoans Schizoporella errata (Walters) in southeastern Brazil. Scientia Marina, 65(3): 173-181.

O'Connor, N.J. and Van, B.T. 2006. Adult fiddler crabs Uca pugnax (Smith) enhance sediment-associated cues for molting of conspecific megalopae. Journal of Experimental Marine Biology and Ecology, 335(1): 123-130.

Oliveira, E. and Masunari, S. 1995. Estrutura populacional de Petrolisthes armatus (Gibbes) (Decapoda, Anomura, Porcellanidae) da Ilha do Farol, Matinhos, Paraná, Brasil. Revista Brasileira de Zoologia, 12(2): 355-371. 
Pinheiro, M.A.A.; Bertini, G.; Fernandes-Góes, L. and Fransozo, A. 1997. Decapod Crustaceans associated to sand reefs of Phragmatopoma lapidosa (Kinberg, 1867) (Polychaeta, Sabellariidae), at Praia Grande, Ubatuba, SP, Brazil. Nauplius, 5(2): 77-83.

Rodríguez, I.T.; Hernandéz, G. and Felder, D.L. 2005. Review of Western Atlantic Porcellanidae with new records, systematic observations, and comments on biogeography. Caribbean Journal of Science, 41(3): 544-582.

Silva, I.M. 2011. Relaçôes filogenéticas entre Pachycheles (Stimpson, 1858) e Neopisosoma Haig, 1960 (Decapoda, Anomura, Porcellanidae) e revisão taxonômica de Pachycheles da costa brasileira. PhD Thesis. University of São Paulo - USP. 105pp.

StatSoft, Inc. 2007. STATISTICA (data analysis software system), version 8.0.

Thiel, M.; Zander, A.; Valdivia, N.; Baeza, J.A. and Rueffler, C. 2003. Host fidelity of a symbiotic porcellanid crab: the importance of host characteristics. Journal of Zoology, 261(4): 353-362.

Veloso, V.G. and Melo, G.A.S. 1993. Taxonomia e distribuição da família Porcellanidae (Crustacea, Decapoda, Anomura) no litoral brasileiro. Iheringia, Série Zoologia, 75: 171-186.

Wilson, W.H. 1979. Community structure and species diversity of the sedimentary reefs constructed by Petaloproctus socialis (Polychaeta: Maldanidae). Journal of Marine Research, 37(4): 623-641. 